\title{
COMMENTS
}

\section{EXPORT COMBINATIONS AND THE ANTI-TRUST LAWS THE DILEMMA OF THE WEBB-POMERENE ACT}

The Webb-Pomerene Act, ${ }^{x}$ granting American export associations certain exemptions ${ }^{2}$ from the Sherman Act, has been on the statute books for thirtytwo years. It was passed largely because American business feared a postwar decline in the export trade that had been built up during the first world war. Because other governments encouraged combinations, it was thought necessary that we should have export combinations so that American exporters might "compete" with foreign traders on a more equal basis. ${ }^{3}$ Early commentators, influenced by this background, tended to gloss over the Act's provisos and concluded that the Sherman Act was now "happily restricted to organizations doing a domestic business." 4 The Federal Trade Commission's "Silver Letter" of I $24^{5}$ strengthened this position by suggesting the legality of agreements between Webb associations and foreign producers.

40 Stat. 5 I6 (IgI8), I5 U.S.C.A. $8 \S 6$ I-65 (I94I).

${ }^{2} 40$ Stat. 516 (IgI8), I5 U.S.C.A. $\$ 62$ (I94r). Section 2, which may be said to represent the heart of the Act, reads as follows: "That nothing contained in the [Sherman] Act ... . shall be construed as declaring to be illegal an association entered into for the sole purpose of engaging in export trade and actually engaged solely in such export trade, or an agreement made or act done in the course of export trade by such association, provided such association, agreement, or act is not in restraint of trade within the United States, and is not in restraint of the export trade of any domestic competitor of such association: And provided further, That such association does not, either in the United States or elsewhere, enter into any agreement, understanding, or conspiracy, or do any act which artificially or intentionally enhances or depresses prices within the United States of commodities of the class exported by such association, or which substantially lessens competition within the United States or otherwise restrains trade therein."

3 I Federal Trade Commission, Report on Cooperation in American Export Trade 372 (I9I6). The bill passed both houses of Congress overwhelmingly. Nevertheless a few like Senator Borah of Idaho feared the Act would "lead to ... the final repeal of the Sherman anti-trust law." $5^{6}$ Cong. Rec. 72 ( $\left.19 \times 8\right)$. For a complete analysis of all the arguments, pro and con, presented at the time of the Webb Act's passage, see Weaver, The Webb-Pomerene Act (I927).

4 Associations for Export Trade, 88 Cent. I. J. 205, 206 (rgIg). Montague, The Webb Bill and the Anti-Trust Laws, 3 A.B.A.J. I45, I56 (IgI ) states: "The purposes of the Webb Bill ... are to fix... geographical bounds to the anti-trust laws...." See also Kirsch, Foreign Trade Functions of Trade Associations: The Legal Aspects, 76 U. of Pa. L. Rev. 89I, $90_{3}$ (I928). Nor was the bench free from such comment. Judge Manton of the second circuit noted in passing that "by the Webb Act the Sherman law has been repealed, in so far as it applies to foreign commerce." Ex parte Lamar, 274 Fed. 160, 172 (C.C.N.Y., I921). For a similar view today, see Oppenheim, Cases on Federal Anti-Trust Laws 66 (r948).

$s$ The letter was written in response to an inquiry regarding certain hypothetical issues raised by the silver producers and was published in a news release of August 6, rg24. See Temporary National Economic Committee, Monograph No. 6, 76th Cong. 3d Sess., at I25 (1940). 
The first definitive judicial interpretation of the Webb-Pomerene Act, however, did not occur until I949 when a federal district court handed down its decision in United States v. United States Alkali Export Ass' $n .{ }^{6}$ This case may well set the direction for future Webb Act interpretations. More important still, it raises the basic question of the inherent workability of the Act itself.

The United States Alkali Export Association (hereafter referred to as Alkasso), one of forty-six associations organized under the Webb Act, ${ }^{7}$ executed a series of agreements with foreign alkali producers dividing among them most of the world's markets. Certain areas were assigned as exclusive territories, others as joint territories, and quotas were established for each member. ${ }^{8}$ Alkasso promised to observe the quotas and exclusive areas assigned. Moreover, any shipments by other American exporters who were not members of Alkasso were to be subtracted from Alkasso's quota in the joint territories. 9 The alkali association acknowledged these agreements at the trial and had in fact earlier communicated their broad outlines to the Federal Trade Commission. ${ }^{\mathrm{o}}$ It denied, however, the government's contention that the United States was a territory covered by the agreements, and it claimed legality for the arrangement under the Webb Act provision which exempts from the Sherman Act "an agreement made or act done in the course of export trade by such [Webb law] association." II

In addition, the complaint charged that Alkasso eliminated practically all domestic export competition by means of exclusive agency contracts, ${ }^{\mathrm{r2}}$ an elaborate espionage system, blacklists of distributors who "bootlegged" the

686 F. Supp. 59 (N.Y., I949). This case is to be distinguished from United States Alkali Export Ass'n v. United States, 325 U.S. I96 (I945), affirming 58 F. Supp. 785 (N.Y., I944), where the defendant's motion to dismiss this complaint on the ground that under Sections I, 2, and 5 of the Webb Act the Attorney General was without authority to institute a suit until investigations and recommendations had first been made by the Federal Trade Commission, was rejected. Other cases involving the Webb Act have also been of relatively minor importance. Branch v. Federal Trade Commission, I4I F. 2d 3r (C.A. 7th, I944), involved Section 4, which extended the scope of the unfair competition clause of the Federal Trade Commission Act, 38 Stat. 7 I9 (Igr4), I5 U.S.C.A. \$ 45 (r94r). United States v. Electrical Apparatus Export Association, C.C.H. Trade Reg. Serv. I 57,546 (D.C. N.Y., I947), is merely a consent decree. In American Export Door Corp. v. John Gauger Co., 154 Wash. 514, 524-28, 283 Pac. 462, 465-66 (I929), there is dictum. United States v. United States Steel Corp., 25I U.S. 4I7, 453 (I9I9), and Ex parte Lamar, 274 Fed. x60, I72 (Ig2I), mention the Webb Act in passing.

7 These forty-six represent 492 member companies, mills, mines, factories, and export houses throughout the United States. C.C.H. Trade Reg. Serv. Iro,243 (I945).

${ }^{8}$ United States v. United States Alkali Export Ass'n, 86 F. Supp. 59, 65 (N.Y., 1949).

9 Complaint, exhibits A, B, C (paragraph II), and D (paragraph 3). Ibid.

so Tbid., at 65 .

II 40 Stat. 5 I6 (IgI8), I5 U.S.C.A. $\$ 62$ (I94r).

${ }^{12}$ Such exclusive clauses were stricken from the membership agreements in 1940 after the Federal Trade Commission had suggested their illegality, but the court found that "as a matter of practice... members ... considered Alkasso their sole agent for foreign sales...." United States v. United States Alkali Export Ass'n, note 8 supra, at 75. 
material into other channels going abroad, the insertion of "for-domestic-useonly" clauses in its sales contracts, and the purchase of all surplus alkali. ${ }^{\times 3}$ Prior to I940 Alkasso controlled over 90 per cent of all alkalis exported from this country. ${ }^{\mathrm{I} 4}$ The association, representing practically all the leading American alkali producers, ${ }^{15}$ was also charged with attempting to remove surplus caustic soda ${ }^{16}$ from the domestic market for the purpose of stabilizing the domestic price of that product.

The court first considered the question of whether the agreements, as they were acknowledged by Alkasso, came within the protection of the Webb Act. To decide this, Judge Kaufman went to the intent of Congress, which he found in the "entire emphasis" of the Federal Trade Commission's Report of rgI6 recommending the bill ${ }^{7}$ and in certain statements of Representative Webb and Senator Pomerene..$^{8}$ The "plain intent of the statute," the court found, was to further competition, not to restrain it. ${ }^{\mathrm{x}}$ Referring also to the "contemporaneous interpretation of the anti-trust laws," ${ }^{20}$ and arguing from Section 4 of the Webb Act which broadens the scope of the Federal Trade Commission Act, ${ }^{2 x}$ the court held that "international agreements... allocating exclusive markets, assigning quotas in sundry markets, fixing prices on an international scale, and selling through joint agents are not those 'agreements in the course of export trade' which the Webb Act places beyond the reach of the Sherman Law." ${ }_{22}$ By thus holding that such international agreements by Webb associations are

${ }^{13}$ The formation of the California Alkali Export Association, otherwise known as "Calkex," was, according to the court, "an integral part of the plan to control the exports of domestic competitors.... [T] he primary purpose of its organization was to withdraw California ash from the already apportioned territory of Norway, New Zealand and Australia, and to market it in conjunction with and under the direction of Alkasso." United States v. United States Alkali Export Ass'n, note 8 supra, at 76.

14 Ibid.

Is Tbid., at 62. The Solvay Process Company, however, withdrew from membership in I94I. Page 9 of the complaint.

${ }^{6} 6$ The term "alkalis" includes soda ash (sodium carbonate), caustic soda (sodium hydroxide), and bicarbonate of soda.

17 United States v. United States Alkali Export Ass'n, note 8 supra, at 69.

${ }^{18} \mathrm{Ibid}$., at 70 n. 18 . See Diamond, The Webb-Pomerene Act and Export Trade Associations, 44 Col. I. Rev. 805, 8 II (I944).

x9 United States v. United States Alkali Export Ass'n, note 8 supra, at 67.

${ }^{20}$ Ibid., at yo.

2x Tbid., at 67,68 . Section 4 of the Webb Act grants world-wide operation to the prohibition against unfair methods of competition contained in the Federal Trade Commission Act. Inasmuch as price maintenance, the establishment of quotas, and the supression of competition had already been held to be unfair methods of competition, the court argues that Section 2 could not possibly mean that "the cartel agreements involved herein are sanctioned under the Act." This argument, however, would invalidate all agreements by Webb associations to fix prices or establish quotas whether made with foreign producers or not. Such obviously was not the intent of Congress.

2 Ibid., at 70 . Italics added. 
per se beyond the scope of the Act's protection, the court rejected the FTC's "Silver Letter" which had suggested the legality of such agreements so long as they did not affect domestic conditions, ${ }^{23}$ and the Commission's later adherence to a test of reasonableness. ${ }^{24}$

Judge Kaufman then went on to dispose of the questions of fact presented at the trial. He first found that the United States was by tacit implication a territory reserved to Alkasso, so that, quite apart from the above-mentioned interpretation of the Webb Act, the arrangement was illegal by virtue of the proviso of Section 2 which withdraws all immunity from any agreement, understanding, or conspiracy "which substantially lessens competition within the United States or otherwise restrains trade therein." ${ }^{25}$ The court also found that Alkasso had engaged in practices designed to eliminate its export competitors in direct contravention of the Webb proviso making the anti-trust exemption inapplicable to any agreement or act "in restraint of the export trade of any domestic competitor of such association." ${ }^{26}$ And finally, Judge Kaufman found that Alkasso did use the association to remove from the market surplus caustic soda in order to stabilize the domestic price in direct violation of the Webb proviso against any agreement, understanding, or conspiracy "which artificially or intentionally enhances or depresses prices within the United States. ${ }^{{ }_{27}}$ In thus serving notice that the Webb Act gives no blanket exemption ${ }^{28}$ from the anti-trust laws to export associations, the Alkasso case falls into a general pattern of narrow judicial construction of Sherman Act amendments that give immunity to special groups. ${ }^{29}$

23 TNEC, op. cit. supra note 5 .

${ }^{24}$ In the matter of Florida Hard Rock Phosphate Export Ass'n, 40 F.T.C. 843 (I945); In the matter of Phosphate Export Ass'n, 42 F.T.C. 555 (x946). With respect to these decisions and to the "Silver Letter," the court said: "[T] he Commission is not entrusted with enforcing the Sherman Act.... In any case, administrative interpretation must fall where clearly unsanctioned by law. ..." United States v. United States Alkali Export Ass'n, note 8 supra, at $7 \mathbf{r}$.

${ }^{25} 40$ Stat. $5^{16}$ (I9I8), I5 U.S.C.A. $\$ 62$ (I94I). See note 2 supra.

26 Ibid. ${ }^{27}$ Ibid.

${ }^{28}$ See note 4 supra.

29 United States v. Frankfurt Distilleries, Inc., 324 U.S. 293 (I945), and United States v. Bausch \& Lomb Optical Co., 32 I U.S. 707 (r944), construing the Miller-Tydings amendment, 50 Stat. 693 (I937), I5 U.S.C.A. \& I (I94r). United States v. Borden, 308 U.S. I88 (I939), construing the Capper-Volstead Act, 42 Stat. 388 (r922), 7 U.S.C.A. $\$ \$ 29 r-92$ (I939), and the Agricultural Marketing Agreement Act of 1937 , 50 Stat. 248 (r937), 7 U.S.C.A. \& 67 I (I939). American Cooperative Serum Ass'n v. Anchor Serum Co., I53 F. 2d 907, 912 (C.A. 7th, I946), cert. den. 329 U.S. 721 (I946), construing the Anti-Hog Cholera Serum and Virus Act, 49 Stat. 78r (r935), 7 U.S.C.A. $85^{2}$ (I939). Contra: United States v. Hutcheson, 3I2 U.S. 2 I9 (1940), construing Section 6 of the Clayton Act, 38 Stat. 73I (Igr4), r5 U.S.C.A. \& I7 (I94I); North Little Rock Transportation Co. v. Casualty Reciprocal Exchange, 85 F. Supp. 96x (Ark., I949), construing the Insurance Anti-Trust Moratorium Act, 59 Stat. 33 (r945), I5 U.S.C.A. \&\& IOII-I5 (1948).

In addition, the courts have often relied on congressional intent to interpret narrowly such statutes. Duplex Printing Co. v. Deering, 254 U.S. 443 (rg2I); United States v. Borden, 
While the Alkasso case could have been decided solely on the basis of the Webb Act provisos, it is clear that the court wished to take a broader stand by removing from the protection of the Act international cartel agreements made by Webb associations. Whether reliance on the purported congressional intent was the best method of achieving this result would appear to be somewhat questionable, for there seems to be nothing in the language of the Act itself to suggest that the exempted "agreement[s] made ... in the course of export trade" refer only to agreements made with domestic producers. Moreover, support for permitting some agreements with foreign producers can be found implicit in the proviso which excludes agreements made "either in the United States or elsewhere" which affect domestic prices. ${ }^{30}$

Nevertheless, the conclusion that agreements with foreign producers are not within the protection of the Webb Act could have been reached by another route. The court might have pointed to the provisions of the cartel agreements which placed upon Alkasso the responsibility for controlling all American exports..$^{3 x}$ Such an arrangement made virtually inevitable Alkasso's attempts to restrict other domestic exporters and might by itself be strong evidence of a conspiracy to restrain the trade of domestic competitors. The Federal Trade Commission has in fact prohibited similar agreements requiring deductions for shipments by other American exporters from the quotas of Webb associations..$^{32}$ The court might then have gone on to say that the only international cartel arrangement which makes sense to the participants is one which includes such a covenant. ${ }^{33}$ But to have made this argument would have been to question

308 U.S. I88 (I939). But cf. Pepsodent Co. v. Kraus Co., 56 F. Supp: (La., I944), where the court used congressional intent to broaden the immunity granted by the Miller-Tydings amendment.

Other Sherman Act amendments providing exemptions for certain groups await construction by the courts. They include: The Bulwinkle Act, amending the Interstate Commerce Act, 62 Stat. 472 (I948), 49 U.S.C.A. $\$ 5$ b (Supp. I949); the Anti-Inflation Act, 6I Stat. 945 (1947), 50 U.S.C.A. $\$ \S$ I9II-r9 (Supp. I950), as amended by Pub. L. No. 6, 8Ist Cong. 2d Sess. (1949); the Civil Aeronautics Act of 1938,52 Stat. 977 (1938), 49 U.S.C.A. $\$ 40$ r (Supp. I948); the Fisheries Cooperative Marketing Act, 48 Stat. I2I3 (r934), I5 U.S.C.A. $\$ 52 \mathrm{I}$ (r94I); Section 29 of the Merchant Marine Act of 1920 , 4 I Stat. 1000 (r920), 46 U.S.C.A. $\S 885$ (b) (r948).

${ }^{30} 40$ Stat. $5 \times 6$ (IgI8), I5 U.S.C.A. $\$ 62$ (I94I). Italics added. See 63 Harv. L. Rev. 364 , 365 (1949), noting United States v. United States Alkali Export Ass'n, note 8 supra.

${ }^{3 x}$ Note 9 supra. In one of its early cartel agreements, Alkasso expressly obligated itself to "take the necessary steps to control Inyo and any other makers of alkali products in the U.S.A." Exhibit B to the complaint, United States v. United States Alkali Export Ass'n, note 8 supra.

${ }^{32}$ Recommendations for the Sulphur Export Corp., 43 F.T.C. 820 (I947); Recommendations for the Florida Hard Rock Phosphate Export Association, 40 F.T.C. 843 (1945).

33 The court did give several hints in the direction of this argument. "The practices engaged in to this end were pursued as a direct consequence of the international cartels and forcefully indicate why such international restraints of trade are interdicted by the Sherman Act and in no way sanctioned by the Webb Act." United States v. United States Alkali Export. Ass'n, note 8 supra, at 74. "This strong solicitude for those in this country who would be 
openly the workability of the Webb Act itself.

It may well be that all Webb associations will inevitably confict with some proviso of the Webb Act. First, there is the impetus to control supply inherent in the purposes of the Act. Webb associations were established to enable American exporters to compete with foreign combinations on an equal plane by controlling the bulk of supply available for export. ${ }^{34}$ For any export association to control supply, however, it obviously must find a way of eliminating or restricting the exports of those who do not enter the association. Otherwise "outsiders" will enter the export field and take business away from the Webb association, thereby rendering it ineffective. Thus, any Webb association, quite apart from its international commitments, will from the force of economic necessity attempt in some way to restrain the trade of its domestic export competitors. This perhaps explains why Webb associations have operated most successfully in those industries where three or four companies account for a very large percentage of the total production. ${ }^{35}$ That the impetus to control supply is inherent in the Act was brought out vividly by the dissenting opinion in American Export Door Corp. v. Gauger. ${ }^{36}$ The FTC's report in rgr6 anticipated this danger $^{37}$ and recommended that it be met by strictly limiting the right to combine to those engaged solely in the export trade (which was never done),,$^{38}$ and by rigidly enforcing Section 4 of the Act extending the scope of the Federal Trade Commission Act (which has been done only recently). ${ }^{39}$

forced to compete with such associations abroad would be entirely frustrated if such cartel patterns as were established here were permitted under the Act. For as long as one rival of an export association sought to vend his wares in foreign territory, international agreements of the kind here involved could do naught but restrain his trade.... Nor can the stifling effect of such arrangements upon potential competition be overlooked." Ibid., at 67. But cf. the steel cartel agreement after 1939. Diamond, The Webb-Pomerene Act and Export Trade Associations, 44 Col. L. Rev. 805, 823 (I944).

34 Jones, Fistorical Development of the Law of Business Competition, 36 Yale L.J. 35I, 365 (1927).

${ }_{35}$ Diamond, The Webb-Pomerene Act and Export Trade Associations, 44 Col. L. Rev. $805,8 r_{7}$ (I944).

${ }^{36}{ }_{154}$ Wash. 514, 528, 283 Pac. 462, 466 (I929). The defendant contended that "prices cannot be regulated abroad without a control of the source of supply," to which the court answered that it was "not a question which should influence us, nor is it one which we should now decide." Holcombe dissenting replied: "The construction by the majority of the proviso in section $2 \ldots$ implies that that section contains its own death clause. If that be true, the Webb-Pomerene Act is utterly inoperative." Tbid., at 525 and 465 .

${ }^{37}$ I Federal Trade Commission, Report on Cooperation in American Export Trade 9 (Igr6).

${ }^{3}$ The Federal Trade Commission itself opened a loophole with the "Silver Letter" of I924, TNEC, op. cit. supra note 5 , at 127 , by stating that a Webb association might properly limit its functions to price-fixing and the allocation of orders among its members, with the implication that price fixing alone might be lawful on the theory that it was an "act done in the course of export trade."

39 Recent FTC decisions have shown Webb associations less leniency by prohibiting exclusive agency contracts, Recommendations for the Pacific Forest Industries, TNEC, op. cit. supra note 5, at 130 ; by invalidating agreements with nonmembers which required them to 
Secondly, whatever is done by an export association to fix prices on the world market or to control exports (assuming that the association represents a sizeable portion of American producers) will necessarily have some effect on domestic prices. Thus any decision to export an unusually high percentage will obviously reduce the domestic supply..$^{\circ}$ Representatives of the copper exporters frankly admitted this in hearings before the TNEC.4I A Webb proviso denies protection to any act which "artificially or intentionally" affects domestic price, and while the domestic effects of foreign price fixing may or may not be intentional, they are certainly artificial.

In the third place, the Webb Act makes the highly unrealistic assumption that corporations will continue to compete on the domestic market at the same time they are combining to fix prices on the foreign market. As one writer puts it, the Act "attempts to force the participants to play the same game with two sets of rules." ${ }^{2}$ The provisos of the Webb Act were inserted largely because Congress was aware of this pitfall..$^{43}$ Yet the pitfall appears inescapable since knowledge on the part of exporters of a price agreement with respect to foreign markets is bound to have at least some effect on the amount of price competition in the domestic market.44

And finally, it may well be that the primary reason why exporters want to use the Webb Act is to lessen competition within the United States..$^{45}$ Webb associations are said to be advantageous to exporters because they offer a means of economy in sales cost, better freight rates through consolidated shipments, storage and warehouse cooperation, improved service to the buyer through standardization, the ability to bid on large orders, and bigger and better adver-

follow the association's export prices, In re Carbon Black Export, Inc., I8 U.S.L. Week 2043 (1949); and by prohibiting any restriction on imports, In the matter of Export Screw Association, 43 F.T.C. 980 (1947).

${ }^{40}$ Diamond, op. cit. supra note 35 , at 827 , puts the argument neatly: "[T]he domestic market can be affected very seriously by the decision of an export association ... to channel into foreign commerce either an unusually large or an unusually small percentage of the total domestic production. To be sure, the workings of the principle of free competition tend to adjust the price changes resulting from such activity, by forcing some producers out of the market or inducing new ones to enter, as the case may be. But the necessary time lag and the inertia represented by capital requirements may afford the export association an opportunity to reverse the trend and hence maintain the grip of its members on the domestic situation." See also Hoselitz, International Cartel Policy, 55 J. Pol. Econ. I, I2 (I947).

${ }_{41}$ Hearings before the Temporary National Economic Committee, 76 th Cong. $3 d$ Sess., Part 25, at $\mathrm{x}_{3} \mathrm{I} 3 \mathrm{I}-32, \mathrm{I} 3 \mathrm{I}_{5} 8$ (1940).

42 Diamond, op. cit. supra note 35 , at 827. Compare Justice McKenna's remarks in United States v. United States Steel Corp., 25x U.S. 4r7, 453 (r9rg). (I927).

${ }^{43}$ Jones, Historical Development of the Law of Business Competition, 36 Yale 35I, 365

44 Hearings before the TNEC, op. cit. supra note $4 \mathrm{X}$, at $13 \mathrm{I} 5^{8}$.

45 Fournier, The Purposes and Results of the Webb-Pomerene Law, 22 Am. Econ. Rev. I8, 20 (1932). 
tising agencies to create demand. $4^{6}$ The presence in Webb associations of such industrial giants as U.S. Steel, Bethlehem Steel and Anaconda Copper casts serious doubt on the proposition that the so-called economies of combination are the real force behind such associations. ${ }^{47}$ Moreover, the majority of Webb associations formed subsequent to the publication of the "Silver Letter" ${ }^{8} 8$ have left to their members the work of making sales, shipping goods, and collecting payments, while the associations themselves undertook only to fix prices, assign quotas, or both.49

The Alkasso case provides an excellent illustration of the motivating force behind the continuance of Webb associations. Early in the life of Alkasso, the alkali producers were faced with the problem of an "excess supply" of caustic soda brought about by the increasing demand for chlorine which is made by an electrolytic process that produces caustic as a by-product. In an effort to maintain domestic prices, the producers used Alkasso to export as much of the excess caustic as they could. Whenever necessary, Alkasso abandoned preassigned export quotas and granted preferences or "overages" to electrolytic producers. In negotiations with its foreign cartel partners, it frantically sought additional markets to dispose of the surplus..$^{50}$ In addition, Alkasso stored tons of excess caustic in its warehouses, and when this became too expensive it paid the members to keep that material at their plants. In all this, the association was the chief mechanism by which the alkali producers lessened competition on the domestic market..$^{\text {sI }}$

Judge Kaufman's reluctance to question openly the presumptive workability of a congressional act, however, led him to make several confusing statements

${ }^{46}$ Federal Trade Commission, Annual Report for year ending June 30,1927 , at 23 . If these advantages are real, however, we might ask why Webb associations have accounted for an average of only seven per cent of total United States exports. Diamond, op. cit. supra note 35 , at $8 \mathrm{I} 7$.

${ }^{47}$ Hoselitz argues, in addition, that the Webb-Pomerene Act is now used only by large firms who do not really need it. Hoselitz, International Cartel Policy, 55 J. Pol. Econ. I, 24 (I947).

${ }^{8}$ The Commission stated that an association might properly limit its functions to price fixing and the assignment of quotas, and implied that price-fixing alone would be lawful. TNEC, op. cit. supra note 5 , at 127 .

${ }_{49}$ TNEC, Monograph No. 2I, 76 th Cong. 3 d Sess., at 218 (1940).

5० United States v. United States Alkali Export Ass'n, note 8 supra, at 78 . See also page 28 of the complaint. The fact that Alkasso was operating on an export margin ranging only from 4 to I2 per cent of the total production was probably responsible, as much as the district court's decision, for Alkasso's ultimate failure.

5x The inherent unworkability of the Webb-Pomerene Act in this respect may be analogized to the Miller-Tydings amendment, 50 Stat. 693 (I937), 15 U.S.C.A. § I (I94I). Thus, pressure for the writing of resale price maintenance contracts has come primarily from retailers. Edwards, Ground for Repeal of Miller-Tydings Amendment, reprinted TNEC Final Report ${ }^{232-38}$ (1941). If the proviso against horizontal price-fixing in the Miller-Tydings amendment is properly enforced, most, if not all, resale price maintenance contracts may be illegal under the concert-of-action doctrine of the Interstate Circuit case, 306 U.S. 208 (1939). See also the basing-points bill, note 56 infra. 
about the intent of Congress. Chief among these is the declaration that "it was the evil of restraint on commerce which Congress sought to extirpate, and not the creation of a preferred class which was to be free to continue the evil." ${ }_{52}$ This rhetoric blurs the attempted legislative separation of the foreign and domestic market; for it was the evil of foreign monopoly which Congress sought to extirpate by creating a preferred class of export associations immune from the normal anti-trust law on foreign commerce-or at least immune to the extent that American exporters are allowed to combine to have joint selling agencies and to fix prices on the foreign market. The court also says that "Congress did not intend ... to abandon the rule of competition as applied to our export trade." ${ }^{53}$ While strictly speaking the rule of competition was not abandoned, the Act on its face drastically restricts it to the situations outlined in the provisos.

Perhaps Judge Kaufman recognized the futility of the legislative attempt to separate the two markets 54 even though he did not wish to question openly the workability of the Act. Since he preferred the basic Sherman Act approach, he therefore sought out the avenue of judicial interpretation which would give the greatest strength to that Act. It may also be that his broad and ambiguous statements on congressional intent will serve as dicta for further judicial limitations on the exemption given to Webb associations.

The real root of the difficulty lies in the conflicting desires within our antimonopoly tradition. We were so opposed to monopoly that we were willing to sanction American monopolies that could better compete with foreign monopolies. ${ }^{55}$ Yet, somehow we also wanted these new monsters of our legislative whim to continue to obey the do's and don't's of our competitive framework..$^{6} \mathrm{We}$ resolved this dilemma by attempting a rather neat separation of the foreign and domestic markets-a separation, however, which had little connection with reality. ${ }^{57}$ This basic inconsistency in our anti-trust laws was recognized by the Supreme Court as far back as I920 when it said it could not see how one combination of producers could at the same time be both "a beneficial instrumentality in the trade of the world" and "such an evil instrumentality in the trade of the United States that it must be destroyed." 58

52 United States v. United States Alkali Export Ass'n, note 8 supra, at 67.

53 Tbid. 54 See note 40 supra.

${ }^{55}$ Levi, The Anti-Trust Laws and Monopoly, ${ }_{4}$ Univ. Chi. L. Rev. I53, I55 (I947).

${ }^{56}$ The recent basing-points bill is analogous. After stating that it is the traditional policy of the United States to condemn "contracts, combinations, conspiracies, or monopolistic practices in restraint of trade," the bill goes on to say that "it has not been the intent of Congress to deprive individual companies of the right to use delivered price systems ... provided such activities are carried on independently and in good faith, and not through any combination or conspiracy in violation of the Sherman Act. ..." S. 1008, 8rst Cong. rst Sess. (1949).

57 See note 40 supra.

${ }^{68}$ United States v. United States Steel Corp., $25 \times$ U.S. 4I7, 453 (I920). Strong theoretical objections to the Webb Act are given in Fournier, The Purposes and Results of the WebbPomerene Law, 22 Am. Econ. Rev. 18, 19 (1932). 
Moreover, there is a possibility that the whole Webb Act may be contrary to the as yet unadopted International Trade Organization Charter. ${ }^{59}$ Under Chapter V of the Charter, each member of the ITO will agree to "take appropriate measures ... to prevent... business practices affecting international trade which restrain competition, limit access to markets, or foster monopolistic control. ..." ${ }^{60}$ Such business practices are further defined to include price fixing and territorial division of markets. ${ }^{6 x}$ Whether or not Webb associations that confine their activities to domestic export curtailments will ever be subject to complaint is open to conjecture. ${ }^{62}$ It seems likely, though, that international agreements of the kind existing in the Alkasso case will be condemned. ${ }^{6}$

How much of an effect the decision will ultimately have on the current practices of other American exporters is not altogether certain. ${ }^{64}$ The fact that American goods are now enjoying a dominant position in the world markets may, for the time being, offset the desire for combination. ${ }^{65}$ Nevertheless, the Alkasso case does warn Webb associations that the provisos of the Act will be strictly enforced by the courts, and that our regular anti-trust law on foreign commerce will be applied to restrictive agreements made with foreign corporations. ${ }^{66}$ Thus the district court has rejected the FTC's "Silver Letter" of ${ }_{924}$

59 For a good summary of the Charter, see Bronz, The International Trade Organization Charter, 62 Harv. L. Rev. ro89 (I949).

${ }^{60}$ Havana Charter for an International Trade Organization, Art. 46, Ir.

6 Ibid., at Art. 46, 13.

on Wilcox, A Charter for World Trade II 2 (I949), expresses doubt. Nevertheless "[i]t is true that Webb-Pomerene associations are permitted to limit competition among their members. ..." Tbid.

63 Ibid.

${ }^{64}$ The suit was supposed to have been "watched closely by U.S. exporters . . . because it is considered a test of the 1918 statute." New York Times, May 5, I949, p. 230. Industry spokesmen, however, have stated in private interviews that the case will have no effect. As far as the price stabilization charge is concerned, this is somewhat academic since two of the largest caustic producers, Allied Chemicals and Wyandotte, withdrew from the association before the decision was handed down.

But a new flurry of congressional activity has occurred. A hearing on proposed major amendments to the Webb Act was held on Feb. 23, 1950 by the House Subcommittee on the Study of Monopoly Power. One amendment would add a proviso against activities which restrict "any foreign buyer from purchasing, negotiating purchases, or otherwise dealing directly .. . with any person, firm, or corporation. . . ." H.R. 504r, 8rst Cong. Ist Sess. (x949). Another would prohibit from membership in a Webb association any manufacturer producing $30 \%$ or more of the total domestic output of a particular commodity. New York Times, Feb. I9, I950, Sec. 3, p. IF.

${ }^{65}{ }_{63}$ Harv. L. Rev. 364,365 (1949), noting United States v. United States Alkali Export Ass'n, note 8 supra.

66 United States v. Timken Roller Bearing Co., 83 F. Supp. 284 (Ohio, I949); United States v. General Electric Co., 82 F. Supp. 753 (N.J., I949); United States v. General Electric, Carboloy, Krupp, et al., 8o F. Supp. 989 (N.Y., r948); United States v. National Lead Co., 332 U.S. 319 (I947); United States v. General Dyestuff Corp., 57 F. Supp. 642 (N.Y., 1944); United States v. Sisal Corp., 274 U.S. 268 (1927); United States v. American Tobacco Co., 221 U.S. 106 (IgrI). 
and has punctured the illusions held by some ${ }^{67}$ that the Webb law gave export associations a blanket exemption from the Sherman Act. Above all, however, the Alkasso case suggests the possibility that the exemption granted by the Webb Act may prove to be meaningless if the Act's provisos are properly enforced.

\section{TEMPORAL ASPECTS OF THE FINALITY OF JUDGMENTS THE SIGNIFICANCE OF FEDERAL RULE 60(b)}

A prime function of legal systems is the settling of controversies. Settling implies ending, and ending implies finality. Ordinarily, then, when final judgment is entered in a cause, all that remains is execution, the transmuting of law into force.

But there is yet another prime function of law, and that is to do justice between parties. Judgment settles controversies; but the settlement may not necessarily be the most just. Common-sense notions of justice would seem to require that decisions be changed when they do not correspond with prevalent notions of right.

The law has gradually been évolving techniques to allow the victims of incorrect "final" judgments to secure relief in court. The process has been long and slow. The desire for absolute finality is strong, and satisfies both aesthetic and administrative needs. Techniques of appeal and rehearing allow correction of lower court misapplication of law. The development of techniques for working substantial justice has been more difficult in cases where defects of fact rather than of law exist in the judgment, and the time for appeal or rehearing has passed.

At common law a judgment could be set aside during the same term of

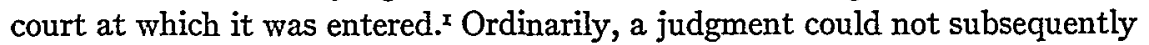
be set aside. Certain types of writs were available to set aside judgments after term, but these were not clearly defined, were cumbersome, and made no pretense of covering all the deserving cases. The two chief writs of this type were the writs of audita querela and coram nobis. Audita querela ${ }^{2}$ lay chiefly for

${ }^{67}$ See note 4 supra. Fortune Magazine also referred to Judge Kaufman's decision as introducing a " 'new' Webb Act." Fortune, Dec. I949, p. I86.

I I Hen. IV, c. 3 (I409): "The records and process of pleas real and personal ... on which judgment was entered and enrolled ... shall not be in any manner amended or impaired ... in any term after such judgment . . . was entered and enrolled." Co. Litt. *260(a): "Yet during the term wherein any judicial act is done, the record remaineth in the breast of the judges of the court, and in their remembrance, and, therefore, the roll is alterable during that term, as the judges shall direct; but when the term is past, then the record is in the roll, and admitteth of no alteration, averment, or proof to the contrary." See also Wooden \& Elizabeth's case, I

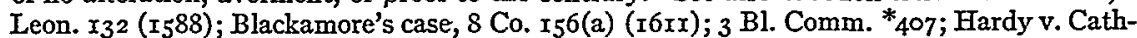
cart, I Marsh C. P. I80, I83 (I8I4); Waldo v. Spencer, 4 Conn. $7 I^{\circ}$ (I82I); Richardson v. Hunt, 7 R.I. 543 ( 1863 ).

2 The writ is of considerable antiquity. "Briefs de audita querela" are spoken of in the Mirror of Justices (Bk. 5, C. I, $\$ \mathrm{I}_{4}$ O) which was written in the late thirteenth century. On 